\title{
Six Years in Achieving Maqasid Ash-Shariah: The Case of Islamic Commercial Banks in Indonesia
}

\author{
Sartini Wardiwiyono \\ Department of Accounting \\ Universitas Ahmad Dahlan \\ Yogyakarta, Indonesia \\ sartini.w@act.uad.ac.id
}

\begin{abstract}
As an Islamic system of values, ethics, and principles, shariah has an ultimate objective that is to promote the well-being of mankind in the world and the hereafter. AbuZahrah further identified the objective of shariah (maqasid alshariah) into educating people, upholding justice and promoting social welfare. As a group of individuals, Islamic business institutions, including Islamic banks, should be operated in any way that is in line with those objectives. The aim of this study is to investigate the practice of Islamic commercial banks in Indonesia in educating people, upholding justice and promoting social welfare as described by Abu Zahrah in his concept of maqasid ash-shariah. Panel data related to financial ratios based on the operationalization of Abu Zahrah's maqasid ash-shariah concept developed by Mohammed $e t$ al. were obtained from the annual reports of 11 Islamic commercial banks in Indonesia. The reports were published in six years' time starting from 2011 to 2016. The data were further calculated to come out with maqasid alshariah index to represent the overall performance of the banks in achieving maqasid al-shariah. To summarize the results, descriptive statistics were finally applied. This study reveals that the thirteen Islamic commercial banks in Indonesia have carried out the necessary activities to achieve the three objectives of shariah. The main focus carried out by the banks is to uphold justice followed by maintaining social welfare. The least priority was given in educating people. During the past seven years, the maqasid al-shariah indexes were fluctuated. The index touched the lowest point in 2014. On average, the maqasid al-shariah index was quite low, opening a room for the banks to improve their activities to be more ethical and social.
\end{abstract}

Keywords-maqasid shariah index, performance, Islamic banks, ethical business, social responsibility

\section{INTRODUCTION}

Islam does not only provide guidance on worshipping God (ibadah), but it also guides Muslim on how to interacting one another and to deal with the environment (muamalah). As a universal religion, Islam has Al Qur'an and Hadith as the main sources of knowledge. Both $\mathrm{Al}$ Qur'an and Hadith contain three main Islamic teachings, which are aqidah, shariah and akhlak. Aqidah is concerned

This study was funded by the Research and Development Institute of Universitas Ahmad Dahlan, Yogyakarta, Indonesia. with Islamic faith; shariah is related to rules and regulation to do action or activities in worshipping God and interacting with God's creatures; whereas akhlak is associated with the Islamic code of ethics.

Among many areas of interactions between Muslim and other fellow human being (muamalah), economics transactions are considered as a prominent area. In line with the basic principle of muamalah stating that everything is permissible in muamalah unless it is clearly prohibited by Al-Quran and Hadith, all kinds of economic transactions are permissible unless it involves any element banned by AlQur'an and Hadith [1]. As Al-Qur'an and Hadith ban economic transaction involving the elements of riba, gharar, maysir, dhalim, and ikhtikar, every economic transaction undertook by Muslim must be free from those elements. Therefore, the existences of Islamic business institutions that are free from those prohibited elements are undeniable.

Currently, Islamic Bank is considered as the most developed Islamic business institution in Indonesia. According to the Indonesian Central Bank's reports, there are 14 Islamic commercial banks, 22 conventional banks with Islamic business units, and 165 Islamic rural banks in Indonesia at present. As a financial intermediary institution, Islamic commercial bank deals with various types of stakeholders. It does not merely responsible for seeking profit but it also has the responsibility to promote justice and peace in the society and to maintain the balance of the environment [2]. Therefore, Islamic Bank is accountable for achieving the objective of shariah (maqasid ashshariah) [3].

However, current Islamic bank performance measurement tends to prioritize the profit-seeking aspect and tends to neglect the achievement of maqasid ashshariah. Reference [4] developed Maqasid Shariah Index (MSI) to measure Islamic Bank's performance. The index was developed based on the concept of maqasid ash shariah as described by Abu Zahrah. In his "UshulFiqh" book, Abu Zahrah explains that shariah in Islam has three purposes, which are: Tahzib al-Fardi (Educating Individuals), Iqamah Al adl (Upholding Justice) and Jalb Maslahah (Producing Prosperity).

Performance measurement based on Maqasid as-Shariah index is considered to be more capable of reflecting the performance of Islamic banks that is in line with the objective of the establishment of Islamic Bank. Based on the 
above description, the current study is intended to describe the performance of the Islamic banks in Indonesia based on Maqasid ash-Shariah Index.

\section{LITERATURE REVIEW}

\section{A. What is Islamic Bank?}

According to the Indonesian Law No. 21 years 2008 on Islamic banking article number one, Islamic banks are banks that carry out their business activities based on shariah principles. The activities of Islamic Bank must be free from interest (riba). The revenues (expenses) of Islamic Bank received (paid) from (to) customers and other parties depend on the contract and agreement made by the customer and the bank. The contents of agreements (contracts) made by Islamic Bank must be subject to the terms and conditions of the contract as regulated in Islamic law [5].

In carrying out its operations, Islamic banks have three main functions. Firstly, the function of collecting public funds that is usually done by using al-wadiah and almudharabah agreements. Secondly, the function of channeling funds to the public in the form of financing using the sale and purchase agreement (murabahah, salam, istisna), leasing (ijarah) or business cooperation agreements (mudharabah, musyarakah). Thirdly, the function of providing services such as transfer, clearing and other forms of services by using wakalah, kafalah, hiwaalah, or joalah agreements.

Similar to a conventional bank, as a financial intermediary institution, Islamic Bank is also intended for providing financial services through mediating the fund minus parties and fund surplus parties in the society. Therefore, it is also a profit oriented institution. However, in line with the Islamic principles (shariah), Islamic Bank does not only responsible for maximizing profit. As an Islamic institution, Islamic Bank also has responsibility to promote justice and peace in the society and to maintain the balance of the environment.

There are three types of Islamic banks in Indonesia, which are Islamic Commercial Banks, Islamic Business Units and Islamic Rural Banks. Islamic Commercial Bank or Bank Umum Syariah (BUS) is an Islamic bank that is allowed to provide financial services in payment traffic. BUS can play role as a foreign exchange bank and nonforeign exchange bank. Foreign exchange bank is a bank that is permitted to carry out transactions abroad or transaction related to foreign currencies such as international transfer, letter of credit and international payment [6]. As for Islamic Rural Bank or Bank Pembiayaan Rakyat Syariah (BPRS), this bank provides financial services just like the Islamic commercial bank except that BPR is not permitted to deal with payment traffic such as clearing. BPRS may only be owned by Indonesian citizens and/or Indonesian legal entities, regional governments, or partnerships between Indonesian citizens or Indonesian legal entities and local governments [6].

\section{B. Performance Measurement of Islamic Bank}

Performance is an action that can be seen, observed and possible to achieve the expected (goal). Performance can also be defined as a combination of ability, effort and opportunity that can be measured from the results of the work obtained over a certain period of time. The performance measurement of Islamic Bank in Indonesia has been evolving from the conventional model of CAMEL (Capital, Assets, Management, Earnings, Liquidity) through CAMELS (Capital, Assets, Management, Earnings, Liquidity, Sensitivity) and finally into RGEC (Risk profile, Good corporate governance, Earnings, and Capital).

The CAMEL model of bank's performance measurement was first introduced in Indonesia in 1991 when February 1991 Package concerning the nature of bank prudence was issued. The package was issued as a policy impact of the 27 October 1988 policy package (1988 Package). CAMEL developed into CAMELS on January 1, 1997 in America.

CAMELS model was developed in Indonesia at the end of 1997 as a result of the economic and monetary crisis. It is regulated by the Bank of Indonesia's Regulation Number 6/10/PBI/2004 on Rating System for Commercial Banks and Regulation Number 9/1/PBI/2007 on Rating System for Commercial Banks. On 2011, the Bank of Indonesia introduced the Regulation Number No13/1/PBI / 2011 and the Letter No.13/ 24/DPNP to replace the CAMELS model with RGEC model. The replacement took effect on January 2012 replaced the bank's health assessment with the CAMELS method with the RGEC method. Though the CAMELS model is no longer valid for measuring the performance of banks in Indonesia, this model was not applicable for Islamic Bank until 2013. CAMELS model is still in use in Islamic commercial banks until that year.

Islamic commercial banks in Indonesia started to use RGEC model to measure their performance since the issuance of the rule of the Financial Services Authority Number 8/03/2014 on Risk-based Bank Rating or known as RBBR. The RBBR model is almost similar to RGEC model as described in the Bank of Indonesia's Regulation Number No13/1/PBI/2011. RBBR model is also a performance measurement model that is carried out using a risk approach. It includes risk profile factors, corporate governance, profit and capital.

Fig.1 depicts the development of performance measurement models for Islamic commercial banks in Indonesia. The performance measurement models for Islamic banking in Indonesia as illustrated in Fig. 1 still tend to prioritize the profit-seeking aspect. They are less able to portray the other important objectives of Islamic banks that are to promote justice and peace in the society and to maintain the balance of the environment. As a result, measuring the performance of Islamic banks based on the objective of their establishment will provide better picture of their performances. Reference [4] has attempted to develop a performance measurement model for Islamic banking based on the concept of maqasid ash-shariah.

\section{Maqasid Ash-Shariah Performance Measurement}

Literally, maqasid ash-shariah means the objective or goals of shariah. According to Umer Chapra, shariah is an Islamic system of values, ethics and principles [7]. Shariah provides rules and regulations on how mankind should undertake their actions and activities to allow them to achieve their well-being (falah) in the world and in the hereafter. 


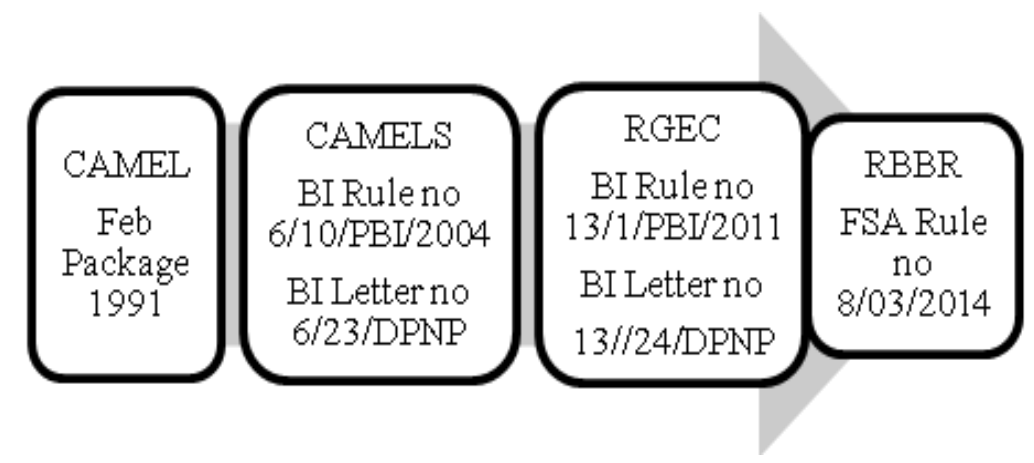

Figure 1. Performance Measurement Models for Banks in Indonesia

According to Imam Al Juwayni, the ultimate objective of shariah is to protect and to achieve maslahah (public's interest). Imam Al Ghazali further described the maslahah by introducing the concept of maqasid ash shariah (the goal of shariah). Imam Al Ghazali's concept of maqasid ash shariah consists of five objectives, which are protection of religion (hifzhad-din), protection of life (hifzh an-nafs), protection of intellect (hifzh al-aql), protection of offspring (hifzhannasl)and protection of wealth (hifzh al-mal). Those five objectives of shariah are then famously known as the five basic needs of mankind. Furthermore, Imam Al Shatibi divided maqasid as-shariah into three different level of objective, namely essential objective (maqasid daruriyyat), complementary objective (maqasid hajiyyat) and embellishment objective (maqasid tahsiniyyat) [8]. The daruriyyat objectives was actually similar to Imam $\mathrm{Al}$ Juwayni's maslahah concept that was further classified into the protection of the five basic needs of mankind as elaborated by Imam Al Ghazali.

Some more recent Muslim scholars operationalized the maqasid ash-shariah into more contemporary concept. One of them was Abu Zahrah (1898-1976). The Abu Zahrah's concept of maqasid ash-shariah was then adopted by Mohammed et al. as a benchmark for performance measurement of Islamic banks. Abu Zahrah stated that the existence of Islamic Shari'ah is a mercy to mankind, so that the purpose to be achieved in establishing shariah in general can be divided into three objectives.

The first objective of shariah is educating individuals (tahdhib al fard) so that each individual becomes a source of good for his community rather than a source of evil. Various forms of worship in Islam are intended to train the soul to avoid the evil so that harmony in the society can be obtained. In the context of Islamic Bank, Mohammad et al. translated this objective into advancement of knowledge, instilling new skills and improvements, and creating awareness of Islamic banks. Those objectives can be measured using several ratios namely education grant to total income ratio, research expenses to total expenses ratio, training expenses to total expenses ratio, publicity expenses to total expenses ratio [4]. The interpretation of these four ratios is that the higher the value of the ratio, the higher the funds allocated for education, research, training and publication and, thus, the better performance of Islamic Bank in achieving the objective of shariah in educating people.

The second objective of shariah is upholding justice (Iqamah al $A d l$ ) so that justice in all areas of human life is created. In all matters of worship, every human being is taught to respect the rights and perform the duties of his party. All human beings are equal before the law. There is no difference between the rich and the poor, the strong and the weak. They have the same obligation of respecting the rights of others and carrying out their duties. In the context of Islamic banks, upholding justice includes three main activities, namely giving returns to interested parties, implementing the distribution function and providing interest-free products. It can be measured using profit to total revenue ratio, profit sharing based financing to total investment ratio, and interest-free income to total revenue ratio.

The third objective of shariah according to Abu Zahrah is maintaining public interest (Jalb al Maslahah). Referring to the concept of maslahah by Imam al Juwayni, Imam Al Ghazali and Imam Al Shatibi, the achievement of public interest (maslahah) could be considered as the core objective of shariah because it leads to the protection of religion, soul, property, intellect, and posterity/wealth. In the context of Islamic banks, maintaining public interest can be done through optimizing profitability, redistribution of income and wealth, and investing in the vital real sector. The performance of Islamic banks is getting better as the net profit earned, the zakat paid and the investment in the vital real sector gets higher. When the investment of Islamic Bank in the real sector becomes more dominant, the support of Islamic banking in maintaining public interest will get higher [4].

\section{RESEARCH METHOD}

This study utilizes panel data related to financial ratios based on the operationalization of maqasid ash shariah concept developed by Mohammed et al. The data were obtained from the annual reports of 11 Islamic commercial banks in Indonesia that were published in the Financial Services Authority's website [10]. The annual reports were published in seven years' time starting from 2011 to 2016. The data were further calculated to come out with maqasid ash shariah index to represent the overall performance of the banks in achieving maqasid ash shariah.

As stated earlier, the maqasid ash shariah index is based on the index developed by Mohammed et al. Based on the results of a number of interviews with Muslim scholars, Mohammed et al. recommended that each objective has different proportion to represent the importance level of each objective. The proportions are as follows: $30 \%, 41 \%$ and $29 \%$ for educating individuals, upholding justice and 
maintaining public benefit, accordingly. To summarize the results, descriptive statistics were finally applied.

\section{RESULTS OF DATA ANALYSIS AND DISCUSSION}

Descriptive statistics are used to summarize the data related to the performance of 11 Islamic commercial banks in Indonesia from 2011 to 2016 based on the maqasid of shariah model developed by Mohammed et al. The results of the analysis are presented in Table 1, Fig. 2 and Fig. 3.

Table 1 shows that the average value of the performance of Islamic commercial banks using the maqasid of shariah model is 0.737 . This finding is higher than the performance of Islamic Bank in Malaysia based on maqasid ash shariah index as reported by reference [4].

\begin{tabular}{|c|c|c|c|c|}
\hline \multicolumn{1}{|c}{ TABLE 1. THE AVERAGE PERFORMANCE OF ICBS } \\
\hline \multirow{2}{*}{ Year } & \multicolumn{4}{|c|}{ Average Performance of Indonesian ICBs } \\
\cline { 2 - 5 } & $\begin{array}{c}\text { Educating } \\
\text { People }\end{array}$ & $\begin{array}{c}\text { Upholding } \\
\text { justice }\end{array}$ & $\begin{array}{c}\text { Promoting } \\
\text { Social } \\
\text { Welfare }\end{array}$ & $\begin{array}{c}\text { Maqasid } \\
\text { Shariah } \\
\text { Index }\end{array}$ \\
\hline $2011-2016$ & 0.0293 & 0.6041 & 0.1043 & 0.7371 \\
\hline
\end{tabular}

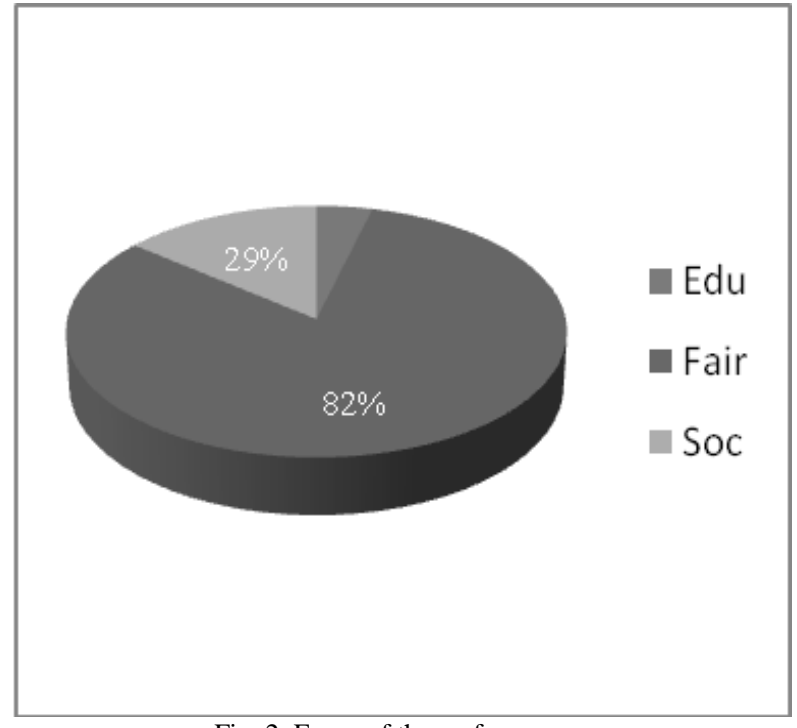

Fig. 2. Focus of the performance

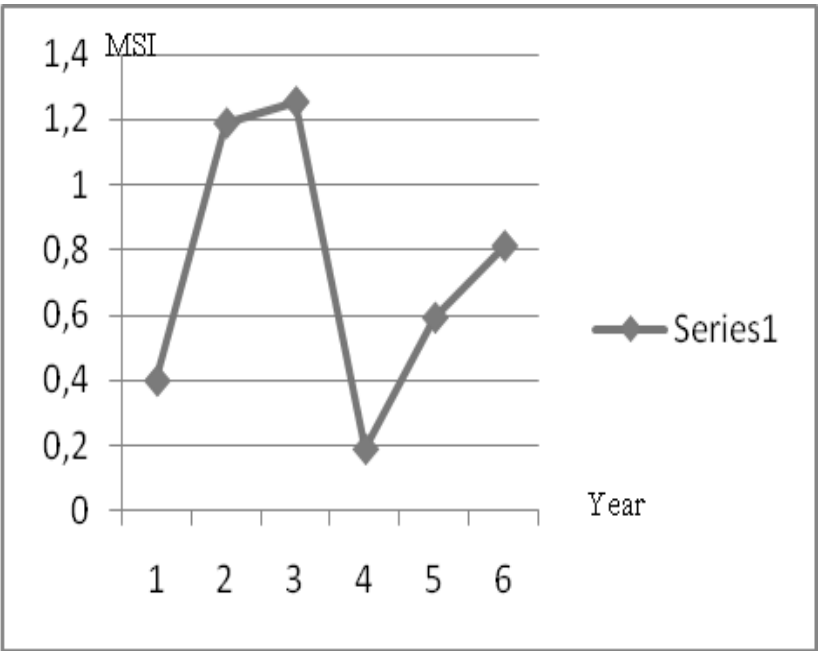

Fig. 3. Development of the MSI in 2011-2016
The performance of Islamic commercial banks in Indonesia based on maqasid ash-shariah index can be further analyzed based on the focus of each objective. Fig. 2 presents the performance of Islamic commercial banks in Indonesia from 2011 to 2016. The figure shows that Islamic commercial banks in Indonesia heavily focus on activities in upholding justice. The activities of upholding justice dominated the entire achievement of maqasid ash shariah with a high percentage of $82 \%$. This value is twice the percentage recommended by Mohammed et al as stated earlier.

With regard to the other two objectives, it can be seen from Fig. 2 that the percentage of achieving the goal of educating individuals is only $14 \%$, whereas the percentage of achieving the objective of maintaining public benefit is only $4 \%$. It means that Islamic commercial banks in Indonesia do not even reach half of $30 \%$ recommended by Muslim jurists in achieving the goal of educating individuals and far below the percentage of $29 \%$ recommended by Muslim scholars through Mohammed et al in maintaining public benefits.

In relation with the development of the maqasid ashshariah index, Fig. 3 illustrates that the maqasid shariah index (MSI) was fluctuated during the period of observation. In 2011, the performance of Islamic commercial banks in Indonesia as measured by MSI reached a value of 0.4 from the maximum value of 3 . Then, the performance shown a sharp increase in 2012 followed by a slight increase in 2013 before finally experiencing a drastic decline in 2014. The year of 2014 was recorded as the year with the lowest performance. The decline in performance is in line with the Financial Services Authority or better known as Otoritas Jasa Keuangan (OJK) report which states that the banking industries in Indonesia were experiencing a decreasing performance at the end of 2014 [9].

The decrease was marked by slowing down of capital adequacy ratios and banks' profitability. According to the Deputy Commissioner for OJK Banking Supervision, the slowdown was caused by the declining global financial problem as well as domestic political factors, especially the 2014 Indonesian General Election.

In line with the improvement of performance of the national banking system in 2015, the performance of Islamic commercial banks based on maqasid ash shariah index also slowly increased in 2015 so that they could return to their previous point. The increase continues to occur so that in 2016 Islamic commercial banks in Indonesia were recorded a 0.8 maqasid shariah index, which was higher than the average maqasid shariah index in the last six years of observation.

\section{CONCLUSION}

As for the conclusion, the current study provides several notable inferences. Firstly, the average performance Islamic banks based on maqasid ash-shariah index from 2011 to 2016 was 0.737 . Secondly, the highest performance value is aimed at upholding justice (0.604), followed by maintaining the benefit (0.104) and finally educating individuals (0.029). Thirdly, the development of Islamic commercial banks' performance during 2011-2016 was fluctuated.

This study has been done carefully. However, there are still opportunities to be improved because the latest data in 
this study data 2016. This is because at the time of the data analysis started, the data of 2017 and 2018 had not been published. Therefore, next researchers are expected to be able to conduct research using the latest data and involve all Islamic commercial banks registered at OJK.

\section{ACKNOWLEDGMENT}

The author would like to thank to the anonymous reviewers and the participants of The 1st International Conference on Science, Health, Economics, Education and Technology for their invaluable comments. Highly appreciation also goes to three research assistants who had assisted the author in collecting the data. Last but not least, the author would also like to thank to her husband and kids for providing endless support.

\section{REFERENCES}

[1] S. Wardiwiyono, "Islamic Corporate Social Responsibility Disclosure in the Organization of Islamic Cooperation Countries," PhD thesis. University of Huddersfiel UK, 2017.

[2] M.H. Kamali, "Maqasid al Shariah Made Simple," London: The International Institute of Islamic Thought, 2008.

[3] A.Sudrajat and A. Sodik,"The Performance Measurement of Islamic Banks Based on Maqasid Shariah Index in Indonesia: Case Study of 9 Islamic Commercia.1 Banks in 2015," Journal of Islamic Business and Management, pp. 182-184, November 2016.

[4] M.O. Mohammed, D.A. Razak, and F.D. Thaib, "The Performance Measureus of Islamic Banking Based on the Maqosid Framework," IIUM International Accounting Conference, 2008.

[5] K. Umam, "Islamic Banking: the Foundations and the Developmental Dynamics in Indonesia," Depok: Rajawali Press, 2016.

[6] A. Soemitro, "Bank and Shariah Financial Institutions," Jakarta: Pranamedia Group, 2009.

[7] M.U. Chapra, "The Future of Economics: An Islamic Perspective," Leicester: The Islamic Foundation, 2000.

[8] S. Wardiwiyono, "Toward Sustainable Success through Corporate Social Responsibility Disclosure: An Islamic Approach," International Journal of Green Economics, vol.7, no. 1, pp.86-101, 2013.

[9] DetikFinance, "The Performance of Banking is Slowing Down at the End of 2014," https://finance.detik.com/moneter/d-2831511/kinerjaperbankan-indonesia-melambat-di-akhir-2014, 15 August 2019.

[10] Financial Services Authority, "Islamic Commercial Bank Financial Statements," retrieved https://www.ojk.go.id/id/kanal/perbankan/datadan-statistik/laporan-keuangan-perbankan/Default.aspx, May 2018. 